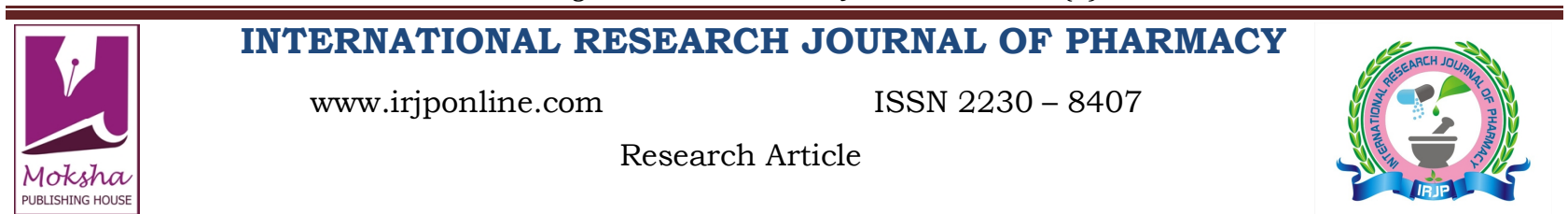

\section{ETHNOBOTANICAL STUDIES ON OCIMUM SPP IN RAJASTHAN, INDIA}

Shashi Agarwal, Vijay R Kumar and Ashwani Kumar*

Biotechnology Lab., Department of Botany, University of Rajasthan, Jaipur, India

Email: Ashwanikumar214@gmail.com

Article Received on: 19/02/13 Revised on: 08/03/13 Approved for publication: 01/04/13

DOI: $10.7897 / 2230-8407.04446$

IRJP is an official publication of Moksha Publishing House. Website: www.mokshaph.com

(C) All rights reserved.

\section{ABSTRACT}

Medicinal plants have served as a major source of new pharmaceutical products and relatively in expensive preparatory materials for the production of some very popular drugs. It is evident, from ethnobotanical survey, that indigenous people use wide range of plants therapeutically to maintain their health. Ocimum called Tulsi is the most sacred plant is regarded as a goddess and worshipped as in deity form. Tulsi is not only sacred plant but also possesses therapeutic properties. From ethnobotanical survey, it is clear that the traditional healers of Rajasthan are having commendable knowledge of the medicinal values of plants growing around them. This knowledge is now fast disappearing and there in urgent need to document this precious knowledge. Present investigations document the ethnobotanical information about Ocimum spp.

Keywords: Ocimum, Traditional healers, Ethnobotany

\section{INTRODUCTION}

India has one of the oldest, richest and most diverse cultural traditions associated with the use of medicinal plants in the form of traditional systems of medicine $e^{1-3}$. Every household in India has a recipe from elders to cure the routine diseases with home remedies. However no proper documentation of such remedies exists. Recently, many developing countries have engaged into studies of traditional medicine, devoting significant attention to migrant communities in industrialized countries. However, Western Europe studies have been scarce in this field ${ }^{4}$. Kala ${ }^{5}$ described use of medicinal plants in different systems of traditional medicine viz. Siddha (1121 species), Unani (751 species) and Tibetan (337 species). Plants have been used by tribals and local people for cure of various diseases. As most of the diseases of modern society are life style disease and the use of herbal medicines can overcome such problems ${ }^{6}$. More over several difficult diseases have problem related with vitality, diabetes, memory loss, could be cured effectively by use of herbal medicine, which is generally not possible by the Allopathic medicines ${ }^{7-9}$ Sharma and $\mathrm{Kumar}^{10}$ have conducted studies on Ayurvedic crude drugs for cure of digestive diseases, leprosy, skin diseases, malaria and paralysis. Ethnobotanical studies have been conducted on different plants of family Trigonella foenum-graceum, racemosus ${ }^{11}$ AdhatodavasicaEuphorbia tirucalli ${ }^{12-17 .}$. Information about medicinal plants traditionally used for therapeutic purposes is mainly deficient because archive material is not systematized and mostly presented in small ethnographic papers published in native languages.).

Ethnobotanical knowledge about medicinal plants is very ancient in India. Rural communities in the Thar Desert, depend on plant resources mainly for herbal medicines, food, forage, construction of dwelling, making household implements, sleeping mats and for fire and shade. During earlier investigations studies have been conducted on ethnobotanical and pharmacognostical characterization of medicinal plants (Kumar, 2000; Cordell and Colvard, 2005). In Rajasthan also a lot of work has been done on ethnomedicinal plants used for various ailments by different tribal communities. Several species of this genus in the plant family Lamiaceae (Lamiaceae) are economically important because of the production of essential oils, especially Ocimum tenuiflorum, Ocimum basilicum, O. americanum, $O$. xcitriodorum and O. gratissimum, and they also have been used medicinally for a large number of ailments and as insect repellents.

However, no work has been done on the Lamiaceae for Rajasthan region. The present work records the plants of ethnomedicinal significance occurring in the Jaipur region of Rajasthan which may be used in future as plant resources for modern system of medicine.

Study Area

Jaipur division of Rajasthan is spread over the Bharatpur, Sikar, Alwar, Dausa, Karolietc (Figure 1).

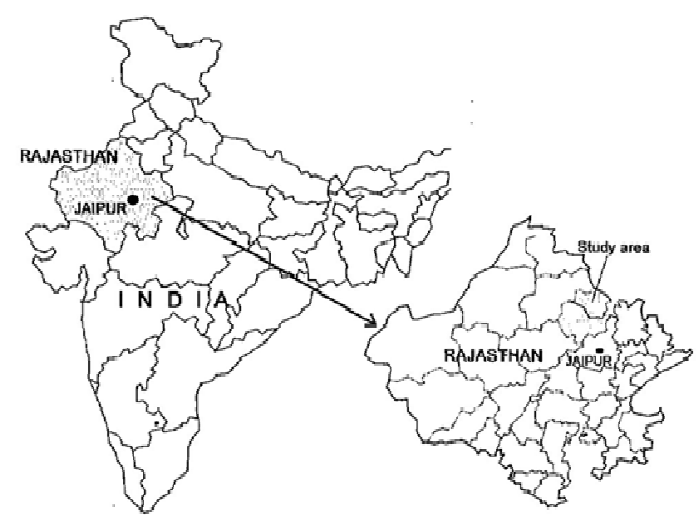

Figure 1. Location map of study area in Rajasthan

\section{METHODOLOGY EMPLOYED}

The traditional knowledge of plant based remedies rests with the medicine men and they maintain it as closely guarded secret within the family. Generally, they do not keep any written document and pass it to the next generation through practice and discussion. The medicine men collect the plants needed for a particular application either directly from the vegetation or from the local shops. In view of such secretiveness of traditional medicine men and women it was decided to interview a number of elderly people who have a great deal of practical know-how of this subject. 
Enumeration

After careful screening some of the important species of angiospermic plants have been recognized as important ethnomedicinal plants from this region of Rajasthan.

Informant Consensus Factor (ICF) and relative importance of plant use (Use Value, UV)

For data analysis, Informant Consensus Factor (ICF) (Heinrich et al., 1998 and Gazzaneoet al., 2005) was employed to indicate how homogeneous the information is. All citations were placed into ailment categories for which the plants were chosen randomly, or if informants do not exchange information about their use. Values will be high (near 1) if there is a well defined selection criterion in the community and/or if information is exchanged between informants (Table 1).

The ICF was calculated as in the Following Formula:-

Where

$$
\mathrm{ICF}-\frac{\mathrm{Nur}-\mathrm{Nt}}{\mathrm{Nur} 1}
$$

Nur = Number of used citation in each category;

$\mathrm{Nt}=$ Number of species used.

\section{RESULTS}

Informant Consensus Factor of Ocimum species of different ailments is given in Table-4.3. During the present survey, forty eight citations were consulted for nineteen diseases. The information is mainly available for Ocimum sanctum L. and Informant Consensus Factor is near 1.0 for all the diseases surveyed.

The Use Value (UV), a quantitative method that demonstrates the relative importance of species known locally, was also calculated according to the following formula:

Where

$$
\mathrm{UV}=\frac{\Sigma \mathrm{U}}{\mathrm{N}}
$$

$\mathrm{UV}=$ the use value of a species; $\mathrm{U}=$ the number of citation per species; $\mathrm{N}=$ the number of informants.

The UV value of Ocimum tenuiflorum $\mathrm{L}$. is calculated as in the following formula:

$$
\begin{gathered}
\mathrm{UV}=\frac{\Sigma \mathrm{U}}{\mathrm{n}} \\
=\frac{48}{119} \\
=0.4
\end{gathered}
$$

The use value of Ocimum tenuiflorum L. is 0.4 .

Table 1: Informant Consensus Factor of Ocimum spp. categorized by medicinal use for corporal ailment

\begin{tabular}{|c|c|c|c|}
\hline Ailment & Species used & No. of Citations used & Informant Consensus Factor (ICF) \\
\hline Radio-protective & 1 & 7 & 10 \\
\hline Anticarcinogenic & 1 & 3 & 1.0 \\
\hline Antidiabetic & 1 & 5 & 10 \\
\hline Antimalarial & 1 & 4 & 1.0 \\
\hline Cardiac activity & 1 & 4 & 10 \\
\hline Immunologic & 1 & 3 & 1.0 \\
\hline Antiinflammatory & 1 & 2 & 1.0 \\
\hline Wound healing & 1 & 3 & 10 \\
\hline Asthama (allergy) & 1 & 2 & 10 \\
\hline Antigenotoxic & 1 & 3 & 10 \\
\hline Gastroprotective & 1 & 1 & 10 \\
\hline Gene transcription & 1 & 2 & 10 \\
\hline Anthelmintic & 1 & 1 & 10 \\
\hline Analgesic & 1 & 1 & 10 \\
\hline Antifertility & 1 & 1 & \\
\hline Central nervous system & 1 & 3 & \\
\hline Eye & 1 & 1 & \\
\hline Thyroid activity & 1 & 1 & \\
\hline Hypolipidemic & 1 & 1 & \\
\hline
\end{tabular}

The Tulsi is the most important plant of family Lamiaceae and is often seen at numerous Hindu temples, especially those dedicated to Vishnu and Krishna. It is commonly grown in the courtyard wherein pilgrims circumvent it, water it, or even offer prayers to it.

Some temples will even have Tulsi groves, wherein one may see numerous Tulsi plants. Some temples will even have a special greenhouse just for taking care of Tulsi plants. These temple gardens provide leaves to prepare large garlands of Tulsi leaves and manjaris (the ends of the branches) for the deity of Lord Krishna to wear. It is commonly associated with devotion of the community.

Vaishnava devotees also use the wood to make neck beads and wear two or three strands of them around their necks signifying their devotion to the Lord. They also make their japa mala or chanting beads from wood of the Tulsi plant as well. Tulsi is personified with a devotee of the Lord Krishna who has taken the form of a tree. Therefore, this plant gets utmost respect. This is one of the reasons for many devotee
Hindus to grow Tulsi in their homes which is considered an important part in the spiritual life of many devotees.

A number of passages in the Puranas and other scriptures (Vedas), point to the importance of Tulsi within religious worship. Tulsi is regarded as a goddess (Lakshmi) and a consort of Vishnu. A garland of Tulsi leaves is the first offering to the Lord as part of the daily ritual. Tulsi is accorded the sixth place among the eight objects of worship in the ritual of the kalasha, the container of holy water.

According to one story, Tulsi was a gopi who fell in love with Krishna and so had a curse laid on her by his consort Radha. She is very dear to Vishnu. Tulsi is also mentioned in the stories of Mira and Radha immortalized in Jayadev's Gita Govinda. One story has it that when Krishna was weighed in gold, not even all the ornaments of his consort Satyabhama could outweigh Him. But a single Tulsi leaf placed on one side his consort Rukmini, tilted the scale.

Tulsi is ceremonially married to Vishnu annually on the eleventh (DevuthanEkadashi) bright day of the month of Krishna in the lunisolar calendar. This festival continues for 
five days and concludes on the full moon day, which falls in mid-October. This ritual, called the "Tulsi Vivaha", inaugurates the annual marriage season in India.

In the Christian tradition it is said that Tulsi grew around the place of crucification. Tulsi is also mentioned in Shiite writings.

- "As by chanting the name of Ganges, one becomes free from all kinds of worldly sins, if someone chants the name of Tulsi or chants the glories of Lord Hari with devotion, he gets the same merit." - From the Brhan Naradiya Purana.

- "Just by touching Tulsidevi one's body becomes pure. By praying to her, all diseases practically become removed. If one waters her or makes her wet, the fear of Yamaraja (death personified) is destroyed." - From the SkandaPurana.

- "Tulsi is most beloved of Lord Krishna and thus her leaves and flowers are also most dear to Him." - Srila Bhaktisiddhanta Saraswati Thakura

- Tulsi leaf is very, very dear to Vishnu." - A.C. Bhaktivedanta Swami Prabhupada

- Tulsi is worshiped in deity form.

- The presence of a Tulsi plant symbolizes the religious bent of a Hindu family. In many traditions (i.e. Vaishnavism), a household is considered incomplete if it doesn't have a Tulsi plant. Many families have the Tulsi planted in a specially built structure, which has images of deities installed on all four sides, and an alcove for small earthen oil lamp. Some households even have dozens of Tulsi plants on the verandah or in the garden forming a "Tulsi-van" or "Tulasivrindavan" - a miniature basil forest.

- Places that tend to inspire concentration and places ideal for worship, according to the Gandharvatantra, include "grounds overgrown with Tulsi plants." The Tulsi Manas Mandir at Varanasi is one such famous temple, where Tulsi is worshiped along with other devas (devigods/goddesses). Vaishna vites, or followers of Vishnu, revere the Tulsi leaf because it pleases Vishnu the most and thus is an inherent part of offerings of naivedya. They also wear beaded necklaces made of Tulsi stems. The manufacture of these Tulsi necklaces is a cottage industry in places of pilgrimage and temple towns. Another name for Tulsi within the Gaudiya Vaishnava tradition is Vrinda devi, meaning 'the goddess of Vrindavan.'

- A Tulsi plant decorated for worship, with fireworks display.

- Followers of Hindu traditions often keep a Tulsi in front of their house. On a specific day each year known as 'Kartik Shukla Dwadashi' (usually about two weeks after Diwali) there is a tradition where in Tulsi plants will be beautifully decorated with structures made of sugarcane, mango leaves and flowers and then a puja (form of worship) is offered.

- As with Diwali celebrations there are usually clay lamps lit around the Tulsi plant and the house. In some parts of India people will also have firework displays to mark the occasion. In northern India and in GaudiyaVaishnava communities it is called the 'Tulsivivah' or the wedding day of Tulsi with Krishna in his Sila form. There is another celebration called TulsiEkadashi where Tulsi is worshipped on the Ekadashi day.

"The Tulsi is the most sacred plant in India. No plants in the world commands such universal respect, adoration and worship from the people as does Tulsi. It is the plant par excellence" [Indian Botanical Folklore].

"A house with a Tulsi plant in front of it is a place of pilgrimage. The wind that carries the aroma of Tulsi spreads purity wherever it blows".

In India, many traditional Hindus grow Tulsi and have at least one living Tulsi plant. They use its leaves in routine worship; they feel protected by its sacred aura; and they use rosary beads for meditation made from its cut stems.

The Tulsi plant has ties with the Hindu god Vishnu (the preserver) and his worship. Tulsi is acclaimed in India as possessing sattva (energy of purity) and as being capable of bringing on goodness, virtue and joy in humans. In the Puranas (sacred Hindu text), everything associated with the Tulsi plant is holy, including water given to it and soil in which it grows, as well as all its parts, among them leaves, flowers, seed and roots. There are many legends from India regarding the Tulsi plant.

Tulsi is used by Ayurvedic practitioners and laypersons for many health ailments and it has both medicinal and spiritual significance in Ayurveda. Tulsi is also used as a valued culinary herb closely related to the sweet basil plant widely available in the West.

Tulsi is classified as a "rasayana," an herb that nourishes a person's growth to perfect health and promotes long-life. For perhaps 5000 years, Tulsi has considered truly legendary of India's healing herbs. From general well-being to acute critical imbalances, Tulsi's magnanimous healing nature is used and honoured daily by millions.

Tulsi has a long history of medicinal use, and is mentioned in the oldest ancient Sanskrit Ayurvedic text-Charak Samhita (written perhaps $6000 \mathrm{BC}$ and complied approximately 400 $\mathrm{AD}$ ). Tulsi is also mentioned in the Rigveda (Book of Eternal Knowledge), thought to have been written around 5000 BC.

Tulsi in Sanskrit means "one that is incomparable"- one that does not tolerate or permit similarity. It is pronounced in English as "tool-see."

Positive judgments by Indian enthusiasts on the health and therapeutic merits of Tulsi are as pronounced as Chinese and East Asian convictions about the merits of ginseng.

\section{Medicinal uses of Tulsi \\ In Ayurveda}

In Ayurvedic medicine, the Tulsi plant is used as topically for skin conditions like eczema, ringworm and insect bites according to Plant Cultures project of the Medicines and Healthcare Products Regulatory Agency (MHRA) of the United Kingdom. Tulsi contains essential oils and antioxidants which has stress reducing effects in the body. Generally, it is used to decrease fevers, improve lung and digestion issues, reduce the effects of colds, eliminate toxins/poisons and also as a preventive antibacterial measure for infections.

\section{DISCUSSION}

New researches on Tulsi specified that it might potentially be an effective treatment for conditions like high cholesterol, Type 2 diabetes, ulcers, obesity and compromised/suppressed immune systems (from conditions like cancers and AIDS). The traditional uses of Tulsi in Ayurveda said by plant cultures may be because of some intrinsic properties in many varieties of Tulsi essential oils containing eugenol, and various acids having antioxidant and anti-inflammatory properties. 
Ocimum gratissimum (Linn.) commonly found in tropical Asia especially India, where it is used for aromatic baths of fumigations in the treatment of rheumatism and paralysis. The plant is also found in West Africa. In Nigeria, it is found in the Savannah and coastal areas.

In the coastal areas of Nigeria, the plant is used in the treatment of epilepsy, high fever and diarrhea. Whilst in the Savannah areas decoction of the leaves are used to treat mental illness Ocimum gratissimum extract has been reported to have antipyretic and antidiarrhoea activities. Its extract has also been shown to have sedative activity and to have therapeutic benefit in patients with inflammatory joint disease.

\section{CONCLUSION}

Due to changing life style, extreme secrecy of traditional healers and negligence of youngsters, the practice and ethnobotanical exploitation and documentation of indigenous knowledge about the usefulness of such a vast pool of genetic resources is deliberately needed.

Growing interest in the use of natural product and folk medicine has resulted to an increase in the demand for medical plant. This increase in demand puts a threat on natural resources. Knowledge on the use of medicinal plants is enormous but if this is not rapidly researched and recorded, indications are that it will be lost with succeeding generations. An estimated 25 percent of prescription drugs and 11 percent of drugs considered essential by the WHO are derived from plants and a large number of synthetic drugs are obtained from precursor compounds originating from plants. Ocimum spp is one such important plant having many potential uses.

\section{REFERENCES}

1. Jain, S.K.: (1987).Ethnobotany, its scope and various subdisciplines: pp. 1-11. In: A Manual of Ethnobotany. S.K.Jain (Ed.). Scientific Publishers, Jodhpur

2. Kotia, A. and Kumar A. (2001) Some of the common weeds of medicinal value from Rajasthan. Int. J. Mendel 18: 17-20.

3. Sharma, S and Kumar,A. (2002) Ethnobotanical studies on medicinal plant chitrak. Int.J. Mendel 19, 129
4. Pieroni, A., Sheikh, Q.Z., Ali, W., Torry, B. 2008.Traditional medicines used by Pakistani migrants from Mirpur living in Bradford, Northern England. Complement The Med 16:81-86. http://dx.doi.org/10.1016 j.ctim.2007.03.005

5. Kala, C.P. 2005. Current status of medicinal plants used by traditional Vaidyasin Uttaranchal State of India. Ethnobotany Research and Applications 3:267-278.

6. Kumar, A. (2008): Ayurvedic medicines: Some potential plants for medicine from India. In: Recent Advances in Plant Biotechnology, Eds. Kumar, A. and Spory, S. (New Delhi +I.K. International), 680-694.

7. Sharma M. and Kumar, A. (2011): Ethnobotanical and Pharmacognostical Studies of Some Medicinal Plants: Tribal Medicines For Health Care and Improving Quality of Life. Germany. LAMBERT Academic Publishers. 234 pp.

8. Upadhyay, B., Parveen, Dhaker, A.K. and Kumar, A. (2010): Ethnomedicinal and ethnopharmaco-statistical studies of Eastern Rajasthan, India. Journal of Ethnopharmacology 129, 64-86 http:// dx.doi.org/10.1016/j.jep.2010.02.026

9. Sharma, L.K. and Kumar, A. (2007): Traditional medicinal practices of Rajasthan. Indian Journal of Traditional Knowledge 6, 531-533.

10. MeenaR, and Kumar A. (2012) Ethnobotanical survey of medicinal plants from Baran District of Rajasthan, India. The Journal of Ethnobiology and Traditional Medicine. Photon 117 (2012) 199-203

11. Sharma, M., Sharma, A. and Kumar, A. (2011): Ethnopharmacological importance of Asparagus racemosus: A review. Journal of Pharmaceutical and Biomedical Sciences 6, 1-13.

12. Parveen, Upadhyay, B., Roy, S. and Kumar, A. (2007): Traditional use of medicinal plants among the rural communities of Churu District in the Thar Desert, India Journal of Ethnopharmacology 113, 387-399. http://dx.doi.org/10.1016/j.jep.2007.06.010

13. Sharma, L.K. and Kumar, A. (2007): Traditional medicinal practices of Rajasthan. Indian Journal of Traditional Knowledge 6, 531-533.

14. Sharma L.K., Agrawal, G. and Kumar, A. (2003): Medicinal plants for skin and hair care, Indian Journal of Traditional Knowledge 2, 62-68.

15. Singh, K.P., Upadhyay, B., Prasad, R. and Kumar, A. (2010): Screening of AdhatodavasicaNees as Putative HIV-Protease inhibitor.Journal of Phytology Phytopharmacology 2, 78-82.

16. Upadhyay, B., Singh, K.P. and Kumar, A. (2011): Ethno-veterinary uses and informants consensus factor of medicinal plants of Sariska region, Rajasthan, India. Journal of Ethnopharmacology. 133: 14-25. http://dx.doi.org/10.1016/j.jep.2010.08.054

17. Upadhyay, B., Singh, K.P. and KumarA.(2010):Ethno-medicinal, phytochemical and antimicrobial Studies of Euphorbia tirucalliL. .Journal of Phytology 2, 65-77.

Cite this article as:

Shashi Agarwal, Vijay R Kumar and Ashwani Kumar. Ethnobotanical studies on Ocimum spp in Rajasthan, India. Int. Res. J. Pharm. 2013; 4(4):228-231 